\title{
William G. Loy (1936 - 2003)
}

Bill Loy was a longtime member of the American Name Society and served many years on the Editorial Board of Names. He was born on October 13, 1936 in Dawson, New Mexico, and died in Eugene, Oregon, on November 15, 2003. He was the second son of Hubert and Charlotte Loy and attended high school in Duluth, Minnesota, then completed his bachelor degree at the University of Minnesota-Duluth. This was followed by his master's degree at the University of Chicago and Ph.D. at the University of Minnesota-Minneapolis. He married Esther Korpi in 1962 and the couple had two children, David and Ellen. Esther died in 1983 and, in 1986, he married Maude Campbell.

Loy was awarded two Fulbright scholarships allowing him to study in Ireland and Austria. He spent three years on active duty with the Navy in the late 1950s and early 1960s where he served on the USS Tanner mapping the floor of the Persian Gulf. In 1967, Loy was appointed in the Geography Department of the University of Oregon where he taught until his retirement in 1997.

He served as department chair and taught cartography and the physical geography of Oregon. His interest in placenames prompted a class in toponymic research in which students not only studied Stewart and other authorities but actually went into the field to find the origins and histories of local feature names. This writer was occasionally invited to guest lecture and remembers that the question periods were always animated. On the 100th anniversary of the University of Oregon in 1976, Bill produced and edited the 1st edition of The Atlas of Oregon. This compendium of social and physical geography was done in the traditional manner with handdrawn maps and diagrams. He went on to help found the University of Oregon InfoGraphics Laboratory and, in 2001, 
directed the 2nd edition, produced in both hard copy and CDRom by the latest electronic techniques. This work received the Globe Book Award from the Association of American Geographers and the Best Book and Atlas Award from the American Congress on Surveying and Mapping. Loy received numerous other honors, including the Distinguished Service Award from the University of Oregon (2002), Oregon Scientist of the Year (1997) from the Oregon Academy of Science, and Distinguished Alumnus Award from the University of Minnesota-Duluth (1990).

Bill was a long time member of the Oregon Geographic Names Board. He was an active participant who personally visited features in cases of ambiguity. His knowledge of European geography provided this writer with probably the best source of the name of the eastern Oregon community of Nyssa, supposedly named by immigrant Greek railroad workers. He noted the river and island situation similar to the town of Messene in Messenia, once know as Nissi, the local word for island. His knowledge and understanding of toponomy will be missed by all who knew him.

Lewis L . McArthur Portland, Oregon 